logos_i_ethos_2_(33)_2012, s. 25-35

\title{
Janna Voskresenskaia
}

\section{The Real Beauty as Spirit of Facts. The World by A. F. Losev}

\section{Introduction}

Aleksei Losev dedicated the entire life to the research. Is there any question or object that is worth of such a sacrifice? Is there something that deserves one life to be spent just to discover its sense? Or even worse, just to touch the surface of its abysmal and deep origin?

The answer, that A. F. Losev, the author who we are going to discuss in our article, would give

Janna Voskressenskaia (born in Moscow 1985) - graduated in Philosophy at Università Vita-Salute San Raffaele of Milan, is currently a $\mathrm{PhD}$ student in Metaphysics at the same University, working on the project regarding the Russian Silver Age in relationship with the Occidental tradition. Collaborator of Giornale Critico di Storia delle Idee (www.giornalecritico.it/) philosophical review on History of Ideas. Main interests: Philosophy and history of religion, History of philosophy, Russian philosophical tradition, History of Ideas.

us is positive. There is something worthwhile and this something is the same life.

Before we start disclosing the main theme of our paper, we should say some words about the biography of this Russian philosopher. Our travel through the facts of his life will bring us to foresee the secret layers of the existence, as developed in his theory.

Born in Novočerkassk in 1893, grandson of an orthodox priest and abandoned son of an eccentric musician, he grew up with his mother. Quite and faithful, she inspired a sense of inner calm, but also of a strong religious belonging in the future philosopher. From his father he inherited love for the music together with the old violin, that he started playing since he was twelve. A young man Losev became interested in philosophy in his latest school years. Encouraged by his teachers of history and literature, who gave him his first philosophical books 
(complete works of Plato and Solov'ev), he moved to Moscow in order to attend the University: both philosophical and philological classes. During these years he developed a special interest for psychology, pedagogical questions, the ancient and the modern philosophy, as long as for the ancient Greek tragedy and mythology. One of his passions continued to be music: almost every day, he went to Bolshoj to enjoy the sounds of the Italian operas, giving private lessons to maintain this expensive spoil. Incredibly thirsty of life and knowledge, he attended all the most important Russian philosophical personalities of those times, especially circles that were in relationship with the Solovjev's thought and neoplatonism in general. His studies brought him also to read and to comprehend all the greatest modern Occidental authors: Schelling, Bergson, Husserl, Nietzsche and many others partially influenced his earliest works. Nevertheless, philosophy was not the only interest of the young scholar. Another source of inspiration was theology and religious questions, including the anthropological view on it.

His own faith, strong and steadfast, came along with all his decisions, indeed, once got married, he and his wife took their vows. His religious interests were strictly connected with the onomatodox discussions, that split the Orthodox Church in two opposite parties at that time. The fundamental point of collision was based on the status to be recognized to the Name of God. The same term onomatodoxy comes from the ancient Greek and means "the Glory ( $\delta \circ \xi \alpha)$ of the Name (ovo $\mu \alpha)$ ). On one hand, the onomatodox position defended the theory of presence of the divine energies in God's Name, and on the other, the opponents of this old opinion saw in the renewal of the ancient discussion on God's energies, which origins can be already clearly seen in the $13^{\text {th }}$ century, a peril of heresy. Losev maintained in his works and also in his life the onomathodox view, that, as we will see, can be considered the real heart of his philosophy.

But why should we mention an exiled monk, who couldn't openly enter any religious institution due to the hard times that shook his country at the beginning of the $20^{\text {th }}$ century? Why is this monk, whose only monastery was his own body, so important for our theme regarding beauty? 
Attracted by all the aesthetical and theological questions, Losev gradually started to give a shape to his own thought. The strongest point of his theory consisted in the connection between the logical structure of the world, the structure that allows us to think, with its vital part. To Losev, there is no distance between our life and our mind, between senses and rationality. The reason of this relationship stands in the unifying origin of the entire world, which upgrading revelation brings things to the existence.

Great reader of Plato, Plotinus and Dyonysius, and at the same time orthodox believer, Losev described the birth of the universe like something upcoming from the unspeakable principle, that is God, who nevertheless, even though in the unknown way, remain silently present in all the creation. It should be noticed that when we talk about our impossibility to get the complete knowledge of God, this does not mean that we have no cognition of the divine nature at all. Indeed, we should get closer to the world and the elements it is composed with in order to sight the remote origin of life, that is also our life.

One of the most diffused picture of the universe creation we have today is the Big Bang theory: the burst giving life to a primordial material. Even though far from being approved and recognized by the Russian philosopher, this commonly known figure can help us. We should imagine something really similar to understand Losev's words. The birth of the universe as expansion of the ineffable origin.

It becomes necessary to see first of all what the difference is. When we talk about material we are used thinking about organic and inorganic matter, while Losev invites us to encompass in this term also the spiritual world, intended as world of meanings. All the things, necessary, have some material base and some form in order to exist. There is nothing existing in the whole world without matter or sense, for the shape of the things, its form, is what we call meaning. Nonmaterial things would not appear at all, at the same time everything has its own sense that makes the identity of the things. Nothing can exist without an identity that distinguishes things one from another.

Once made our considerations on the material nature of the world, let's turn back to our imagine of the original explosion. We should follow 
a famous imagine and think about a seed that already have all the elements to become a tree, something untouchable and unspeakable that, expanding its own potency, becomes everything, nothing incomes from the outside in it. This is why everything existing is the same expansion of this principle, both hidden and constantly present in all the things, in everyone of us.

Leaving our example and turning back to Losev's philosophy we should start approaching his logical-dialectical explanation of the world's structure.

\section{The First Logical Tetrad}

The dialectics, for Losev, is the universal law of being and thinking, based on contradiction and synthesis. The author suggests a tetrad structure of logics, instead of a traditional triad statement $\left.{ }^{1}: 1\right)$ the first logical category for Losev is the pure One. Indeed, nothing can be thought without a unity criteria, every single thing is first of all "one thing”, even before we know its meaning. The „One”, considered as a very beginning, has no limits and no boundaries as there is nothing out of it that could give a determination to this first category. This situation results unacceptable for logics, as the One, so described, is indeterminate, undistinguished, eventually unknown. The logical thought necessary proceeds. 2) The One, in order to become a real logical category is supposed „to be”, to exist as something (the second principle is being/sense). Logics needs this first principle to distinguish itself, to put down his own limits, to get a form and a meaning. As a consequence, the One becomes plurality: indeed, the One, the absolute identity, is different from the same difference. The identity distinguishes itself from the difference so that it becomes determined, it acquires the limits by itself, as there is no principle of differentiation existing out of it (otherwise the One would not be the first logical category). Here the One becomes a concrete „One”, while in the first category the term was almost improper, as no definition can be suitable for the indeterminate formless beginning. Now the One is One, has and is sense. 
Unity and plurality are two opposite categories that, following Losev's method, should be synthesized. 3) The synthesis of these two logical components is the becoming, indeed the One becomes determined and plural, it moves in order to mould its own face.

This triad contains the first three logical categories (one/unity-pluralitybecoming) that are the basis of all the other possible logical categories and operations, but the author invites us to proceed immediately with the determination of one last category as the dialectical law imposes: how does look the opposite face of the Becoming? What does contradict this tireless flow in order to determinate it? The answer is intuitional: 4) something that has already become, the fact, that reflects all the three previous categories. The real fact indeed is always one single existing fact and it has always sense or meaning. The fact is the hypostatical matter (v' $\lambda \eta)$ realization of sense $(\varepsilon \mid \delta \circ \varsigma)$. This makes of fact a symbolic structure, as it reveals the idea by means of matter.

At this point a brief summing-up can be useful as one more category is going to be considered. The first principle is the absolute and the pure One (1), perfectly unknowable. The One (as determined One, (2)), the being/sense and the becoming (3) are properly categories of sense, finally, the fact (3) is the substance which meaning (form) is given by the sense categories. 5) In this way the fact, considered as related to any other possible fact or category, reflects its sense "outside”, the fact is a mirror, an expression of its inner life, a symbol. The expression is the fifth category that Losev includes in his logical basis ${ }^{2}$.

Since this are categories that should represent the universal logical structure of the world, one question arises: what makes this structure truly absolute? What can guarantee the objective foundation of these categories and what can save them from subjectivism?

Losev gives us an explanation within the already given categories, by the further development of their profound significance.

2 The influence of the great Italian philosopher B. Croce is more than evident here, indeed, this category will be fundamental for the Losev's esthetical thesis regarding the artistic forms essences. See B. Croce, Estetica come scienza dell'espressione e linguistica generale. Teoria e storia, Milano 1990 and B. Croce, Problemi di estetica, Bari 1949. 


\section{The Intelligent Modification of the First Logical Tetrad}

As previously mentioned, the unspeakable One turns to itself in order to get determined. After acquiring limits, the One becomes effectively „One”, that in this way can be defined and perfectly thinkable. The One gives sense to itself. This means that the One enter in a sense-relationship with itself, the One has a cognition of itself, it becomes intelligence, thought. The intelligence so intended is the relation of the tetrad to itself in its every single dialectical moment.

The pure One related to itself, as absolute and unshaped One, gives the ecstasy, that is not properly intelligence, but a complete fusion of the subject with the object. Ecstasy is not the real knowledge, for the knowledge should necessary separate the subject of cognition from the object that should be explored. No distinction of this kind can be made within the first principle ${ }^{3}$.

The second dialectical moment (that can be also called the place of the $\varepsilon เ \delta \varepsilon$, Novৎ) is the real protagonist of knowledge and science. It is a category of a perfect distinction and determination. Here, the One assumes consciousness, finds his limit and the perfect knowledge of itself (that is knowledge of everything, as it is everything), it becomes both subject and object, separate and unified at the same time. The cognition of the second moment is the perfect self consciousness that uncloses the One with all its depth ${ }^{4}$.

The third category, the becoming, contains the second moment (all categories contain the previous ones, as they all are the disclosure of the first principle), but not at the same static way, as this third category is characterized by a continuous life flow. The One moves in order to reach itself, the knowledge of itself is the end of the One, the One „wants” to know and to determine itself, his intelligence is the result of his will, that is the intelligent modification of the Becoming category.

А. Ф. Лосев, Диалектика мифа, Москва 2001.

Idem, Диалектика имени, Москва 2009. 
The fact, the fourth category, has also its own precise intelligent modification, as it is related to all the previous categories, but has a different nature. The fact is the matter of the triad, it embodies the triadic world of the becoming ideas and holds them in its heart, as the most true and real meaning of itself. The cognition that takes place here is the cognition of the body ${ }^{5}$, which is much more than a brute fact: indeed, it is a complete self consciousness where the facts feel their dialectical soul, their inner world as the intimate nature of their being. The fact becomes a living body of eternity, it becomes Sophia ${ }^{6}$.

Regarding the intelligent modification of what we called Expression, Losev in his work Dialectics of Myth tells us that turning to itself the Expression becomes understanding $g^{7}$.

\section{The Final Dimension of the Absolute Dialectics}

The latest definition of fact, as intelligently modified, brings us to consider this category under a different light. Now the fact should be thought as a living being with a perfect self consciousness that allows this concrete existence to read in itself the meaning of life flowing through it.

5 Idem, Диалектика мифа, there is a different definition of the same intelligence modification of the second dialectical moment given in the Диалектика художественной формь, here the author make use of the term "feeling" to define the self cognition of the expression. Indeed, the expression, as a symbolic structure, both contains the factual and the ideal nature, while the fact can be seen only as the matter of the triad (that is the place of becoming ideas). Nevertheless, two definitions are not contradictive, they just put to an evidence two faces of the same question of being. These two works have different aims, the first one considers life. The myth (the „arena for the encounter" of any factual being with any other) is what the real life is for Losev, the life that can't make any distinction between the matter and the meaning, the ideas. In the second work, dedicated to esthetics, Losev highlights the gap between facts and ideas, in order to show how the ,artistic beauty" is connected to a "free play" where the ideal archetype and the created concrete artistic form are at the same time independent one from another, but also necessary chained in the synthesis following the undeniable dialectical law. The difficulties that Losev's language opens are heard to be solved. In our case we should probably intend by Body the myth, already realized as symbol, more than the simple fact.

А. Ф. Лосев, Диалектика имени, ор. cit.

There should be recognized the same aporia that have already been discussed regarding the Fact (see note 4 ). 
This fact, that both is life and intelligence, is what Losev calls person, the most concrete realization of the triadic dialectical sense in a matter.

At this point the previous categories must be revisited as belonging to a person, its part and essence. As already mentioned, the One is the origin of everything existing, thus it would be appropriate to determinate this pure One as something Unborn that Gives Life. What shape can similar category get if considered as a life principle of a person? Losev teaches that the capability of giving life must express the Power, nothing can be done or created if there is no potential possibility of doing or creating it. In the same way the second category, the Intelligence or Nous, that was born as a result of the proceeding of the One, if studied from the personalistic view, becomes the expression of Faith intended as Vision. Eventually the becoming category, that we named Will or Life, in this new logical-dialectical frame is defined by Losev as Love.

The Person, the most concrete and all embracing category, is a realizer of Power, Vision and Love. But who is this absolute person able to fulfill perfectly and definitely the universal triad? What is Power as Person, Vision as Person and Love as Person? Losev explains that we are close to understand the great dialectic mystery of a Christian teachings on Trinity ${ }^{8}$.

Indeed, the Power as Person is the Father, his Power is his Autarchy. The second category, or Nous, that is born from the first category, is the Son while Vision, related to the Son as Person becomes Wisdom. The Life as Person is the Spirit, so that his Love becomes Sanctity, definitions that explain the Holy Spirit nature.

We should now pay our attention to the expression category, that has been left apart in this long and heard dialectic way. What will be the perfect Understanding of the Autarchy of Power, of the Wisdom of Vision, of the Sanctity of Love? What will be the Word, the Name (the most concrete category of expression for Losev) expressing their essence?

With these questions we finally arrived to the disclosure of our initial task. Losev teaches us that the perfect expression of the Autarchy of 
Power is the Good, the expression of the Wisdom of Vision is the Truth and the absolute expression of the Sanctity of Love is the Beauty.

\section{The Real Beauty: Fact as Symbol}

The personalistic understanding of the dialectical categories, as described, was possible only because of the definition of the fourth category: the category of fact in its absolute logical-dialectical development ${ }^{9}$. This category, nevertheless, must be seen in connection with its symbolic nature. It has been already mentioned that the fact hides in itself the endless life flow of the triad One-Being/Sense-Becoming. The fact is a perfect dialectic connection of the triadic sense with the hypostatic matter. This determined hypostasis has its own identity, distinguished from the triad identity, but at the same time its own form is given by the hidden life play of being that takes place in its intimate heart. The structure so defined is what Losev calls expression, but the same expression can combine the inner and the outer parts it connects in a different way. What is the perfect symbol? How should be structured the expression which profound sense and surface must be in a perfect equilibrium?

Losev describes three main ways of being that every expression can have: 1) the inner idea of an expression can bend the outer elements to its will, in this case the expression becomes scheme. Here the factual part of expression is organized following the extrinsic rules dictated by the idea. We can find an example of a similar structure in every mechanism. 2) The inner idea can also remain distant from the factual part of the expression, in this case the factual face is rich and articulated, but the meaning that it should conduct to is showed as unexpressed. Here we should leave the colours that the surface of the expression brings before our very eyes and achieve the highest idea that otherwise cannot be reached. The perfect example of this kind of expression is allegory. 3) There is also the expression which inner idea and factual parts are absolutely balanced. The idea and the thing are intimately connected 
here, the thing is the perfect expression of the idea, while the idea is not a mere generic method, but a concretely given form.

The concept of beauty has been analyzed by Losev in more than one occasion. Esthetics has always been one of the main topics that Losev developed in his works, but we should take distance from the artistic meaning of beauty in order to foresee a deeper sense of this category.

Losev writes in his Dialectics of myth:

The art itself is and must be symbolic or at least symbolic at different levels. But in comparison with the real life it is allegoric. While life is symbolic by its nature, as the way we live is the way we $\operatorname{are}^{10}$.

The author suggests that we move long the life line and this is exactly what we did. It is time to meet the answer given by A. F. Losev to the question regarding the essence of beauty.

Life is a perfect symbol on account of its own structure. It is given by facts that hypostatically reveal the triadic sense of being: One-Being/Sense-Becoming are made flash by means of Fact, the Fact becomes a perfect intelligence of its inner life turning out to be a Person, a Person that has/is Power (Father), Vision (Son) and Love (Holy Spirit). The expression, category that opens the idea through the thick matter of fact allows our research to get to an end. As already seen, Beauty is the expression of the Sanctity of Love.

Devoted to the onomatodox orthodox faith, Losev refuses the rationalism and the apophasis as methods of defining the religious experiences of God. Indeed, the onomatodox theories maintain the absolute symbolism that allows us to foresee God through his energies, given first of all in his Name, the absolute expression, even though his ovoia is ineffable. The same logical-dialectical structure of the world as described by Losev is a reflection of the creation mystery, the author invites the science to leave all the concepts of infinity, deriving from the Newton's mechanics, and to accept the absolute logics as the real law of being, in order to define the universe as 
a determined and perfectly formed structure that is a concrete imitation of God's Name, the imagine of the absolute expression of God ${ }^{11}$.

\section{Afterword}

A. F. Losev was one of the most brilliant authors of the Russian Silver Age, who left a vast philosophical and theological heritage that still should be discovered and deeper analyzed. The concept of beauty he developed is strictly connected to his orthodoxy, that is the real heart of all his theories and works. Everything comes to the existence for the First Principle proceeding. This very first, invisible Father of thing gives life to the entire world which we are part of.

How can we see this our enigmatic roots? The beauty is an occasion to foresee the origin that otherwise can be only thought by means of long theoretical wonderings (rationalism) or defined through the apophatic theology. The real Beauty for Losev is the mirror of the Holy Spirit presence in the world, the Spirit that is the Life, the Becoming principle.

The world reveals us the face of the hidden source of the universe, we can see it in every Fact, as all the facts are the revelation of the One. Losev invites us to consider Beauty as the most proper name of Love, that is the same Life. The author teaches us that Beauty is absolute, but nevertheless it is rooted in the eye of the beholder, we should give a right direction to our inner sight in order to catch the Beauty.

11 А. Ф. Лосев, Имяславие (1919-1920?), essay written in German language, published in Russian translation in „Вопросы философии”, No 3, 1993, p. 52-60. 